\title{
The Commitment to Securing Perpetual Journal Access
}

\section{A Survey of Academic Research Libraries}

\section{Patrick L. Carr}

Current and emerging trends raise questions about the extent to which academic research libraries should continue to seek perpetual access provisions for journal acquisitions. To describe the questions being raised, this paper begins by framing perpetual access commitments within the contexts of the past, present, and future. The paper then assesses current views and practices by describing and analyzing the results of a survey of librarians. The results show that, while the respondents' libraries generally espouse strong commitments to perpetual access, a combination of factors is leading many libraries to take actions that weaken perpetual access provisions.

A $\mathrm{s}$ they transition from print to electronic collections, academic research A libraries are revolutionizing how they acquire, manage, and provide journal access. Despite the scope of these changes, many assume that one constant will endure: the commitment to preserve journal collections. According to this view, changes in formats, tools, and workflows are simply new means for ensuring that current and future generations have ongoing access, which is a goal that will remain unwavering. This paper examines the question of whether academic research libraries are indeed steadfast in their commitments to securing perpetual access to journal acquisitions or if current and emerging trends are driving these libraries to become less stringent in their pursuit of perpetual access. Perpetual access is here defined in accordance with the definition of the Digital Library Federation's Electronic Resources Management Initiative: "the right to permanently access licensed materials paid for during the period of the license agreement."

This paper first places perpetual access within three contexts: the traditional commitment of libraries to preserve their journal collections, the challenges libraries now confront in upholding this commitment, and emerging trends in the information landscape that raise questions about the value libraries will secure for future patrons through the pursuit of perpetual access provisions. The paper then describes the results of an online survey of librarians at the academic member libraries of three consortia: the Association of Research Libraries (ARL), the Association of Southeastern Research Libraries (ASERL), and the Greater Western Library Alliance (GWLA). The description of the survey's results is followed by a discussion of the results' implications.
Patrick L. Carr (carrp@ecu.edu) is Head of Electronic and Continuing Resources, Joyner Library, East Carolina University, Greenville, North Carolina.

Submitted May 22, 2010; tentatively accepted, pending modest revision July 18, 2010; final revision submitted August 7 , 2010, and accepted for publication. 


\section{Background}

\section{The Past: Traditional Commitments to Preserve}

Raven's Lost Libraries surveys the forces that have destroyed library collections across the ages. ${ }^{2}$ From the sacking of ancient Assyrian libraries by Babylonian conquerors to the confiscation of Jewish libraries by the Nazis, Raven chronicles the destruction of collections by such perils as fires, wars, ideological intolerance, mismanagement, and simple abandonment. What unites these losses is their occurrence in environments that, to varying degrees, were characterized by a scarcity of information. In such environments, the barriers to information distribution and reproduction were high and, if bibliographic resources were not protected, access to the information they carried may be lost forever. Libraries emerged in part to prevent such losses and, for each of the catastrophes recounted in Lost Libraries, in innumerable instances libraries have preserved information that would have otherwise perished.

For most of library history, the primary means of preservation was the effective custodianship of scarce holdings. According to separate studies by Higginbotham and McDonald, today's more sophisticated and proactive preservation practices originate in the decades between the founding of the American Library Association (ALA) in 1876 and the outbreak of World War I in 1914. ${ }^{3}$ Both studies show that, during this span, libraries gained a better understanding of the vulnerability of their collections and developed a growing sense of a preservation imperative. As the twentieth century progressed, this imperative was boosted by a variety of factors-most importantly, the perceived "brittle books crisis" and the bibliographic destruction resulting from the 1966 flood in Florence, Italy. By the 1970s, preservation became the focus of an ALA unit, and larger libraries started creating preservation departments and participating in broad preservation initiatives. ${ }^{4}$

In subsequent years, the commitment to preservation has become ingrained as an essential responsibility of academic research libraries. Maxwell, for example, declares that preservation is the "sacred duty" of librarians and the reason why libraries exist. ${ }^{5}$ In more measured tones, this commitment to preservation also is reflected in a number of statements published by the ARL over the past few decades. To take a recent example, Hahn and Blixrud preface a 2009 ARL special report on preservation by asserting, "preservation is a core function of the research library and a key element of both the stewardship and access missions of research organizations."

What distinguishes recent preservation commitments from precursors is the nature of the resources to which libraries provide access. With the ongoing transition from print to electronic formats, preservation practices are becoming more complex. This is particularly true in the case of journals, which have been at the vanguard of the shift to electronic formats. When a library subscribes to a journal in electronic format, it acquires access but usually does not take possession of a copy that it holds locally. While the license agreement associated with the acquisition may contain perpetual access provisions, the means of carrying out these provisions are oftentimes insufficiently developed.

These challenges have sparked a flurry of activity to develop clear, easily adoptable measures that will allow libraries to retain their traditional commitment to preservation. A milestone in this effort was a 2005 meeting hosted by the Andrew W. Mellon Foundation at which library leaders discussed journal preservation. After the meeting, the congregation issued a statement that succinctly captures prevailing views about the severity and urgency of the issues at stake. ${ }^{7}$ This statement, which the ARL later endorsed, ranks journal preservation among the foremost challenges in academia and proceeds to describe the perils:

If a publisher fails to maintain its archive, goes out of business or, for other reasons, stops making available the journal on which scholarship in a particular field depends, no practical means are in place for libraries to exercise their permanent usage rights and the scholarly record represented by that journal would likely be lost. For electronic journals, the academy as of yet has no functional equivalent in long-term maintenance and control over the scholarly record that "owning a copy" provided for printed journals. ${ }^{8}$

To address the crisis, much attention has been devoted to developing solutions for the effective retention of perpetual access provisions. For example, a 2006 report issued by the Council on Library and Information Resources (CLIR) examines twelve emerging archiving initiatives. ${ }^{9}$ Two of these initiatives, LOCKSS (Lots of Copies Keep Stuff Safe) and Portico, have been particularly successful in North America and have achieved participation from a broad spectrum of libraries and publishers. However, even with such initiatives in place, libraries' efforts to reclaim their mantle as stewards of their journal collections are far from complete, a fact reflected in Atkinson's 2005 statement that the inability to acquire journal access that includes ownership represents "the greatest single failure of research libraries in the past decade." 10

\section{The Future: Journals in an Evolving Information Landscape}

The transition from print to electronic formats is only one manifestation of broader changes in how information is 
created, distributed, located, and accessed. Conceptualizing these changes, Darnton writes that they mark civilization's entry into a new stage of information technology. ${ }^{11}$ In Darnton's framework, the world was previously transformed by the development of written communication around 4000 $\mathrm{BCE}$, the codex around $300 \mathrm{CE}$, and printing with changeable type in the 1450s. The latest stage in this progression, Darnton explains, commenced with the emergence of electronic communication networks in the 1970s and the World Wide Web in the 1990s. Among this last stage's greatest impacts has been a transformation from past ages of information scarcity to an age in which the rapid proliferation of information can "seem both unstoppable and incomprehensible."12 Of course, this superabundance of information resides not in the physical world of paper, bound volumes, and stacks, but rather in the virtual world of large-scale digitization, data sets, and cloud computing. What is emerging is a landscape of what Morville has termed "ambient findability," a place from which a person "can find anyone or anything from anywhere at anytime."13

Journals are already part of this ambience. Indeed, researchers have come to expect expansive journal access from the time and place of their choosing. While much of this access is due to subscriptions to "big deal" publisher packages, the ambient findability of journals is also the result of vendors making this content available through pay-perview transactions and the rental service DeepDyve (www. deepdyve.com). The availability of content on these bases is rooted in the "Long Tail," a marketing concept popularized by Anderson. ${ }^{14}$ The Long Tail takes shape in an environment where reductions in providers' inventory and distribution costs combine with technological advancements to empower large and diverse demographics of consumers to easily find and purchase a wide array of niche products. The Long Tail's inclusion of journals and the momentum toward its further expansion into the depths of scholarly literature suggests that, in the future, market forces are likely to make journal content accessible-either directly to researchers or to libraries acting on their behalf-at an affordable cost. This scenario has the potential to decrease the benefits that future patrons will enjoy because of libraries' determination to secure perpetual access for newly acquired journals. Traditional commitments to preserve are rooted in an environment of information scarcity in which technological, geographical, and financial barriers often rendered bibliographic resources as irreplaceable. The emerging environment replaces absolute, physical scarcity with what Hazen terms "the artificial scarcity created through restrictive manipulations of the digital marketplace." 15 If trends progress on their current trajectory, this artificial scarcity, a key basis for Long Tail economics, seems likely to supply a profusion of information that can be easily distributed and affordably acquired.

\section{The Present: Journal Collections at a Crossroads}

The full impact of the emerging information age remains unclear, and, as Plutchak comments, the implications on scholarly communication will not be understood for decades ${ }^{16}$ One result of these uncertainties is that today's justifications for an abiding commitment to perpetual journal access are becoming more speculative. In the printcentered era of information technology, threats to scarce bibliographic resources provided a concrete imperative for libraries to preserve their journals. In contrast, grounds for securing perpetual access usually rely more on past precedents, a mistrust of commercial interests, anxieties about the future of the information marketplace, and the sense that the tremendous cost of acquiring journals is itself an imperative for making them a permanent part of the collection.

Although the speculative nature of these justifications has not been used as grounds for abdicating preservation commitments, they do offer compelling premises in support of arguments that perpetual access can be sought with less stringency. Previous arguments involving the tensions between the access and ownership of e-resources have generally been dispelled by repeating a variation on the truism that it is not a question of either/or but both/and. ${ }^{17}$ Today, this method of resolution is becoming less tenable. Indeed, funding scarcities and fiercely competing priorities confront libraries with painful either/or decisions. For example, the ability to meet patrons' expectations for seamless access is more difficult because of reduced or stagnant budgets and inflating subscription costs. Opportunities exist for libraries to decrease journal expenditures without an immediate decrease in access, but many of the most effective solutions involve the loss of perpetual access, including

- converting subscribed access to access through payper-view transactions;

- cancelling subscriptions to journals with current issues available through full-text aggregators; and

- discontinuing membership in archiving initiatives such as the LOCKSS Alliance and Portico.

Administrators can resist such measures on the grounds that their lack of perpetual access provisions are at odds with a research library's preservation mission, but the cost of fidelity to this mission may be the inability to acquire certain resources and services to meet patrons' current needs.

Accompanying the scarcity of funds to acquire journals is a scarcity of personnel to manage them. As Stachokas argues, the few personnel that most libraries assign with e-resource management responsibilities are dwarfed by the libraries' large and growing e-resource collections. ${ }^{18}$ In support of this claim, the author cites Barnes, who conducted research showing that while libraries typically spend 
about 60 percent of material expenditures on e-resources, only 25 percent of staff have responsibilities for managing these resources. ${ }^{19}$ This finding brings to light a dilemma when considered in the context of Stemper and Barribeau's analysis of e-resource licenses, which shows that most publishers are willing to grant perpetual access during license negotiations. ${ }^{20}$ Although the authors consider these findings heartening, they become considerably less so given the lack of personnel devoted to e-resource management and the significant expertise and time required to carry out effective license negotiations. Administrators can remedy the situation through the allocation of additional personnel to the responsibilities of e-resource management, but such allocations come at the cost of not meeting competing priorities.

The few recent studies of perpetual access provisions suggest that the conflict between libraries' funding and personnel scarcities and the traditional commitment to longterm access has resulted in a disconnect between libraries' stated values and what they accept. From November 2006 through January 2007, Rogers surveyed New Zealand university and polytechnic libraries regarding the portion of the libraries' journals with archival rights or perpetual access provisions. ${ }^{21} \mathrm{He}$ found that, despite the libraries' stewardship commitments, only 30 percent of their licenses explicitly ensured long-term access. Stemper and Barribeau reported similar findings in $2006 .{ }^{22}$ Their literature review and informal survey suggests that more than 80 percent of research libraries in North America will accept an agreement even if it lacks perpetual access provisions.

At the heart of these contradictions are diverging visions of the role of research libraries in the twenty-first century. In one vision, there is an expanded focus on patrons' immediate needs and a moderation of stringent perpetual access commitments. Hazen expresses this outlook when advocating as a guiding principle for the future that libraries "frame their information goals in terms of providing access to content that they do not possess, as well as on-site holdings. ${ }^{, 23}$ Teper charts a different course. ${ }^{24}$ Discussing the importance of maintaining preservation commitments despite funding scarcities, he argues that libraries must distinguish themselves from commercial interests by "recasting themselves as memory institutions in an environment increasingly concerned with on-the-fly access." ${ }^{, 25}$ While time will reveal the outcomes of the tensions between long-term preservation commitments and immediate priorities, important insights about the nature of these outcomes are available through a clearer understanding of how libraries currently describe their commitments to perpetual access. The results of this paper's survey help provide such insights.

\section{Survey Method}

To measure the extent to which academic research libraries are committed to perpetual journal access, the researcher conducted an online survey of librarians with journal acquisition responsibilities at academic libraries in the following consortia: ARL, ASERL, and GWLA. While ARL is the premier consortium of research libraries in North America, ASERL and GWLA also identify themselves as having memberships consisting of research libraries. These two regional consortia include libraries that are too small to hold ARL membership but that consider themselves research libraries. Of ASERL's thirty-eight members, eighteen lack ARL membership; seven of GWLA's thirty-two members lack ARL membership. Because the researcher was interested in the views and practices of both large and small academic research libraries, librarians at these non-ARL libraries were invited to complete the survey. Not surveyed, however, were public libraries, state libraries, and other consortia members that are not a component of a larger institution of higher education. Because of the differences in these organizations' missions, user communities, and staffing structures, the researcher felt that an assessment of their commitments to perpetual access would be better addressed elsewhere.

The anonymous survey, which had eleven questions and is reproduced in appendix A, was approved by the researcher's institutional review board on February 12, 2010. During the subsequent two weeks, the researcher e-mailed invitations to complete the survey. An invitation was sent to the one librarian at each ARL, ASERL, and GWLA institution who, on the basis of information on the library's website (including personnel directories, department pages, and organization charts), has the most direct responsibilities for managing journal acquisitions. In cases where a library's website was unclear about the librarian with primary responsibilities for journal acquisitions, the researcher contacted a higher-level administrator (e.g., a head of technical services). The invitation requested that, if another librarian was better suited to complete the survey, the recipient forward the invitation to that person. In no instance was more than one librarian at a single institution invited to complete the survey. The survey closed on March 16, 2010.

\section{Survey Results}

\section{Respondents' Libraries}

The 136 survey invitations resulted in 48 respondents completing the survey, a response rate of 35 percent. Included within the respondents is the researcher, who completed the survey on behalf of his institution, East Carolina University. An analysis of the replies to survey question 1 shows that 37 of the respondents work at ARL libraries, 10 work at ASERL-only libraries, and 1 works at a GWLA-only library.

Replies to question 2 indicate that 25 respondents work at libraries with a full-time enrollment (FTE) more than 
25,000 . Of the other respondents, 14 work at libraries serving FTEs ranging from 15,000 to 25,000 , and the remaining 9 work at libraries serving less than 15,000 FTE ( 5 in libraries serving less than 10,000 FTE and 4 in libraries serving between 10,000 and 15,000). As a point of comparison between the respondents' libraries and research libraries as a whole, 2007-8 statistics show an average FTE of approximately 24,000 among ARL libraries and 20,000 among ASERL libraries. ${ }^{26}$

Question 3 assessed the funding that the respondents' libraries are providing in the current fiscal cycle for acquiring journal content (including individual subscriptions in all formats, publisher packages, full-text aggregators, and pay-per-view transactions, but excluding one-time backfile purchases and associated fees). Respondents' replies to the question indicate that, while there are some outliers, most work at libraries with funding between $\$ 3$ million and $\$ 6$ million (see figure 1). In comparison, 2007-8 statistics show that ARL libraries spent an average of about $\$ 7.5$ million for current serials, and ASERL libraries spent an average of about $\$ 6$ million for these resources. ${ }^{27}$

Replies to question 4 show that, in comparison with the previous fiscal cycle, the largest number of libraries (21) have experienced no change in their funds for journal acquisitions (see figure 2). Another 18 of the libraries experienced decreases in funding, and the remaining 9 libraries experienced increases in funding.

\section{The Importance Attributed to Perpetual Access}

Questions 5 and 6 examined the importance that the respondents' libraries attribute to perpetual access. In response to question 5, which asked how important the respondents' libraries currently consider perpetual access for journal acquisitions (excluding full-text aggregator subscriptions, nonsubscribed journals that become available through publisher packages, and pay-per-view transactions), most respondents (31) indicated that perpetual access is essential or very important, some (12) ranked perpetual access as somewhat important, and a small number (4) ranked perpetual access as having little or no importance (see figure 3 ).

The results show a small correlation between the funding and FTE of the respondents' libraries and the importance that these libraries attribute to perpetual access. Of the 31 respondents ranking perpetual access as either essential or very important, 58 percent (18) of their libraries have an FTE of more than 25,000 versus 52 percent overall, while just 10 percent (3) have an FTE of less than 15,000 versus 19 percent overall. Likewise, 32 percent (10 of 31) of the respondents ranking perpetual access as either essential or very important (versus 25 percent overall) are spending more than $\$ 6$ million for journal acquisitions in the current fiscal cycle.

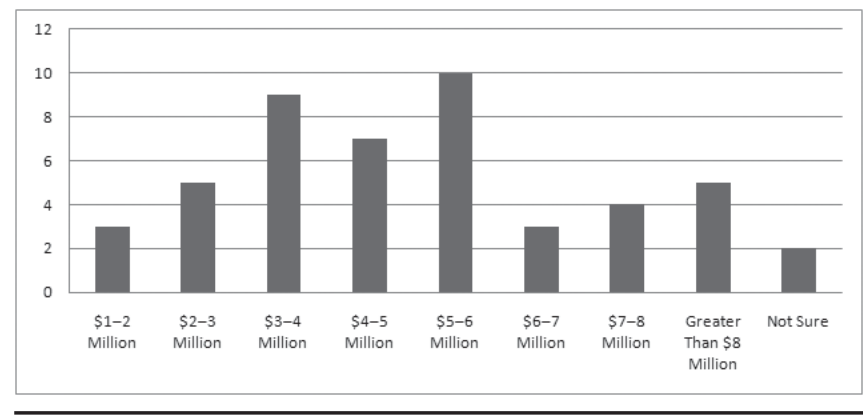

Figure 1. Journal Acquisitions Budgets

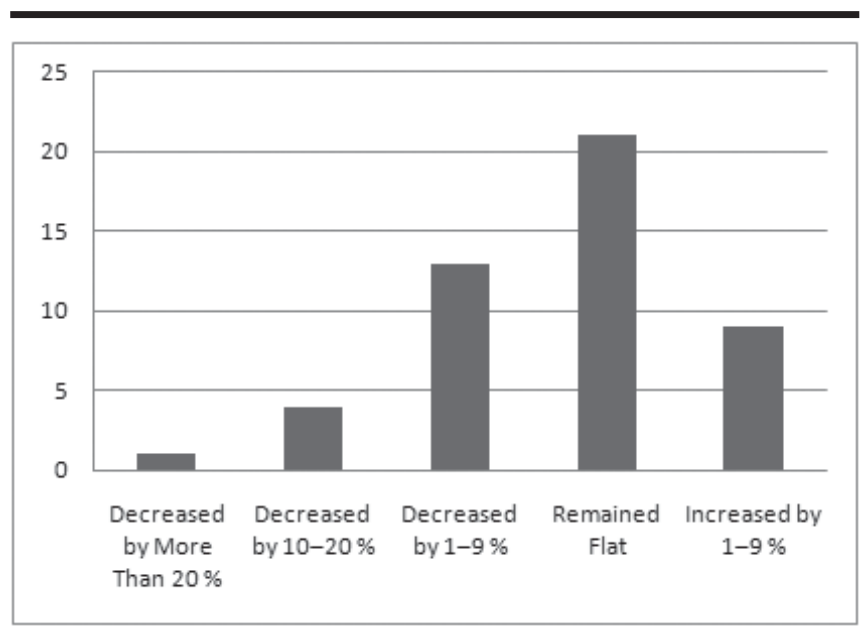

Figure 2. Change in Journal Acquisitions Budgets from Previous Fiscal Cycle

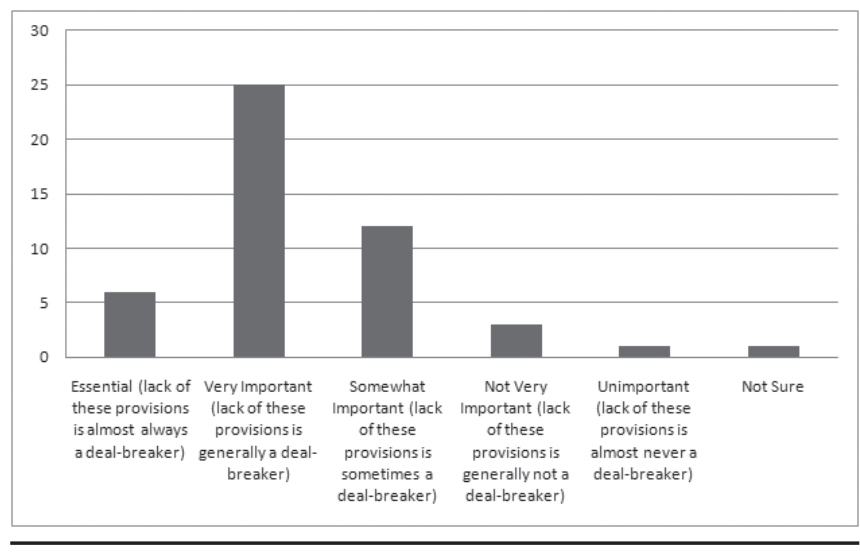

Figure 3. Importance of Perpetual Access Provisions

The results show no clear correlation between changes in journal expenditures of the respondents' libraries and the libraries' differing commitments to perpetual access. Of the 31 respondents who ranked perpetual access as either essential or very important, 45 percent (14) have flat expenditures (versus 43 percent overall) while 39 percent (12) have decreasing expenditures (versus 37.5 percent overall), and 16 percent (5) have increasing budgets (versus 
19 percent overall). Of the 12 respondents who ranked perpetual access as somewhat important, 50 percent (6) have flat expenditures (versus 43 percent overall), 25 percent (3) have decreasing expenditures (versus 37.5 percent overall), and another 25 percent (3) having increasing budgets (versus 19 percent overall). Finally, among the 4 respondents ranking perpetual access as either not very important or unimportant, 2 have flat budgets, 1 has an increasing budget, and 1 has a decreasing budget.

In reply to question 6 , which asked whether the commitment to perpetual access is increasing, decreasing, or remaining the same, 24 indi-

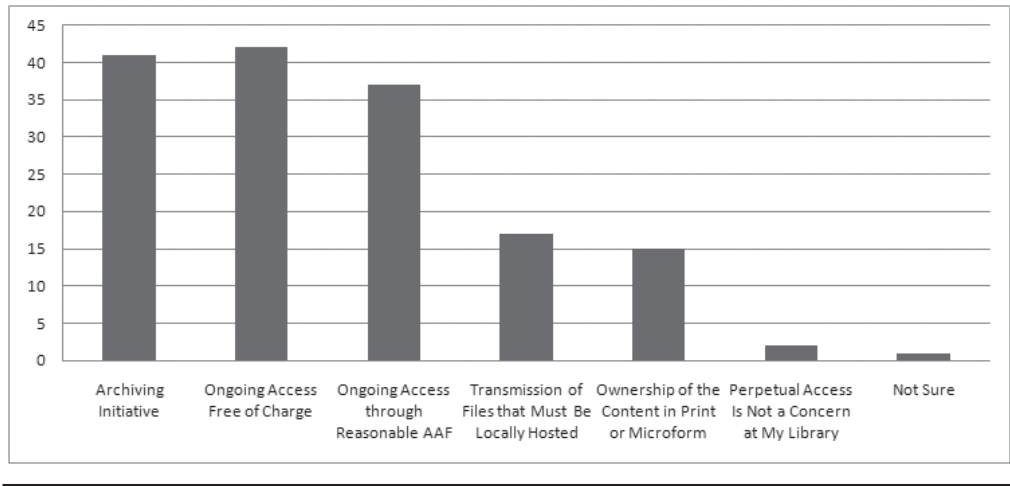

Figure 4. Acceptable Provisions for Perpetual Access cated that this commitment is unwavering, 23 indicated that the commitment is increasing, and one indicated that the commitment is decreasing. A comparison between all responses to question 5 and the 23 responses to question 6 from respondents indicating that perpetual access is an increasing priority shows that the differences in importance that these 23 libraries currently ascribe to perpetual access generally mirror the rankings across all responses. A notable discrepancy is the respondents in libraries that already consider perpetual access to be essential. Whereas just 1 of these 23 libraries already rank perpetual access as essential, 12.5 percent (6) of all respondents ranked perpetual access in this way. Inverting this disproportion are the 24 respondents who indicated that, at their libraries, perpetual access remains at the same level of priority; among these libraries, 22 percent (5) ranked perpetual access as essential. However, also of note regarding these 24 respondents at libraries where perpetual access remains at the same level of priority is that 3 of these ranked perpetual access to be either not very important or unimportant.

\section{Acceptable Terms for Perpetual Access}

Question 7 assessed what provisions the respondents' libraries deem acceptable for securing perpetual access. To do so, it listed five perpetual access provisions that vendors often offer and asked respondents to indicate which of these provisions are acceptable at their libraries (see figure 4). The provision that was most often acceptable (selected by 42 respondents) was ongoing access via a web platform free of charge. The acceptability of this provision is followed closely by participation in an archiving initiative such as LOCKSS or Portico (41) and ongoing access via a web platform subject to a reasonable annual access fee (37). The results show a significant decrease in the acceptability of the other two options listed on the survey. Only 17 respondents affirmed the acceptability of ongoing access via the transmission of files that must be locally hosted, and 15 affirmed the

acceptability of ownership of the content in print or microform.

\section{Budgetary Effects}

Questions 8 and 9 assessed current and anticipated impacts of budgetary trends on commitments to perpetual access. Question 8 asked if budgetary factors have forced their libraries to undertake any of a list of five actions that often weaken the ability to retain perpetual access:

- Discontinuing participation in one or more archiving initiative (e.g., LOCKSS and Portico)

- Canceling subscribed journal access because of aggregator access to the cancelled content

- Converting subscribed journal access to access through pay-per-view transactions

- Converting print subscriptions to online subscriptions lacking perpetual access provisions

- Downgrading subscribed journal access to subscription levels with decreased perpetual access provisions

Most respondents indicated that their libraries have taken one or more of these measures (see figure 5). The most widely taken measure (in 25 libraries) was journal cancellations because of access through a full-text aggregator. Predictably, many of these libraries have experienced reductions in their journal budgets. Indeed, 52 percent (13) have decreased budgets from the previous fiscal cycle compared to 37.5 overall. The second most frequently taken measure (in 19 libraries) was the conversion of print subscriptions to online subscriptions lacking perpetual access provisions. Here, however, no significant correlation exists between these libraries and budget reductions. Far fewer of the respondents' libraries have taken any of the three other measures listed. Indeed, only 5 work at libraries that have been forced to downgrade subscribed access to levels with 


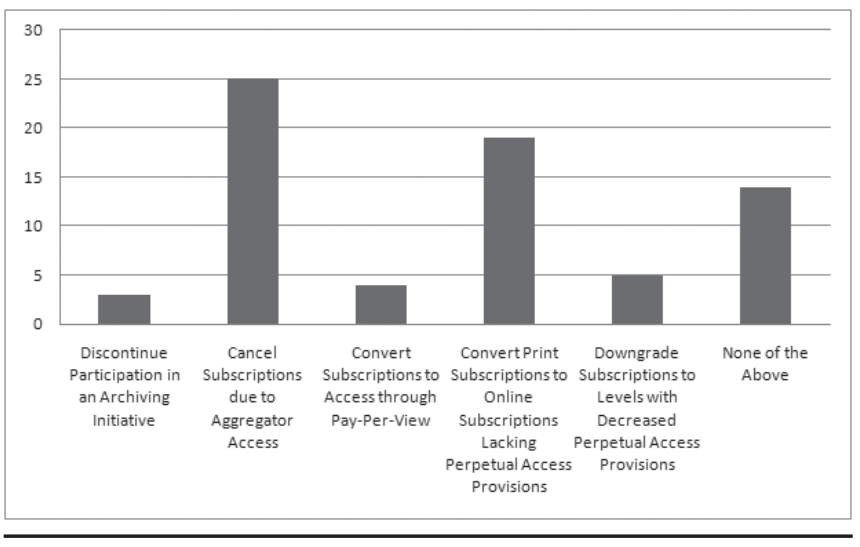

Figure 5. Steps Taken due to Budgetary Factors

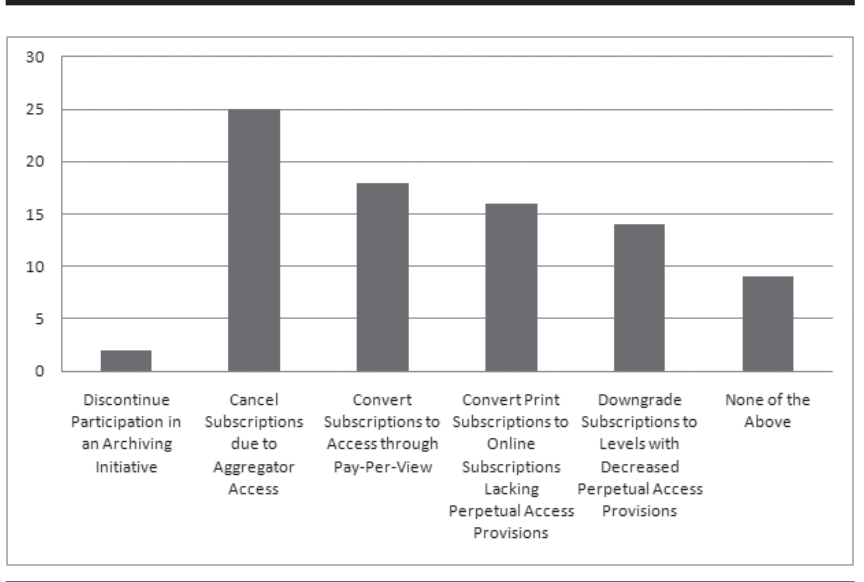

Figure 6. Anticipated Steps to Be Taken due to Budgetary Factors

decreased perpetual access provisions, 4 work at libraries that have been forced to convert subscribed access to access through pay-per-view transactions, and 3 work at libraries that have been forced to discontinue participation in one or more journal archiving initiatives.

Correlations are evident between the numbers of measures taken because of budgetary factors and the budgets and commitments to perpetual access among the respondents' libraries. Of the 15 libraries where at least two measures have been instituted, 47 percent (7) have experienced reductions in their journal budgets from the previous fiscal cycle versus 37.5 percent (18) overall. Likewise, 67 percent (10) valued perpetual access as being either somewhat important or less, versus 33 percent (16) overall. Among the 33 libraries that took any one of these measures, a smaller but still notable correlation with their commitments to perpetual access is present. Forty-two percent (14) valued perpetual access as being either somewhat important or less, versus 33 percent (16) overall. Fourteen respondents indicated that their libraries have not needed to take any of the measures. As would be expected, the budgets and commitments to perpetual access among these libraries invert the correlations observed among the libraries that had to take measures resulting in the loss of perpetual access. Ninety-three percent (13) of these libraries value perpetual access as being very important or essential, and only 21 percent (3) have experienced decreases in journal budgets from the previous fiscal cycle.

Question 9 asked if respondents think that, in the next few years, budgetary factors are likely to force their libraries to take any of the measures listed in question 8. Most respondents expected that their libraries will be forced to take one or more of these measures (see figure 6). The most widely anticipated measure is the cancellation of subscriptions because of access through a full-text aggregator. Twenty-five respondents expected that their libraries will take this measure, the same number that indicated in question 8 that they have already taken the measure.

The second most anticipated measure is converting subscribed access to access through pay-per-view transactions, which 18 of the respondents expected. This number constitutes a drastic increase (450 percent) from the 4 libraries that have already converted subscriptions to payper-view transactions because of budget cuts. What is most notable about the libraries of these 18 respondents is that they generally placed a high value on perpetual access. Seventy-eight percent (14) of these libraries considered perpetual access either very important or essential (versus 65 percent overall) and 56 percent (10) indicated that the value being placed on perpetual access is increasing (versus 48 percent overall).

Third on the list of measures that the respondents predicted their libraries will need to take because of budgetary factors is converting print subscriptions to online-only subscriptions that lack perpetual access provisions. Sixteen respondents predicted this measure, a slight decrease from the 19 that have already undertaken it. In comparison to the respondents that predicted pay-per-view to be likely in their libraries' futures, the respondents that predicted their libraries will convert to online-only subscriptions without perpetual access provisions generally ranked perpetual access as a lower priority. Fifty-six percent (9) of these libraries valued perpetual access as being only somewhat important or not very important, versus 33 percent (16) overall.

Fourteen respondents predicted that budgetary factors will force their libraries to downgrade subscribed journal access to subscription levels with decreased perpetual access provisions. As with respondents predicting their libraries' uptake of pay-per-view, the 14 respondents predicting downgraded subscribed journal access is far more than the 5 who reported this measure has already been taken. Finally, only two respondents predicted their libraries' discontinuation of membership in an archiving initiative. These 2 are also distinguished by the fact that they are among the few in 
the survey who had responded that their libraries consider perpetual access to be either of little or no importance.

Nine respondents did not believe that their libraries will need to take any of the measures. Seven of these 9 respondents also had been among the 14 respondents that answered the previous question by indicating that their libraries have not needed to take any of the measures. As was the case with those 14 respondents, the 9 currently in question have disproportionately healthy journal acquisition budgets. Whereas the percent of respondent libraries with budget cuts was 37.5, none of these 9 respondents work at libraries that have experienced budget cuts.

\section{The Impact of Not Securing Perpetual Access}

Question 10 asked what impact any loss of journal content because of lack of provisions for perpetual access has had on their libraries' abilities to support the research, teaching, and learning of their user communities. No respondents replied that the impact on access has been major, but 25 percent indicated that they had experienced minor losses in access. Seventeen respondents indicated no such losses, and 6 indicated that they are not sure if losses have occurred. The factor that differentiates the respondents indicating impacts-albeit minor ones-because of a lack of perpetual access provisions is the value they ascribe to perpetual access. Compared with the 65 percent (31) of respondents indicating that these provisions are either very important or essential, 52 percent (13) of those respondents with minor losses in access consider these provisions to be either very important or essential.

\section{Error Analysis}

Conclusions that can be drawn from the survey's results are limited by the methods used to conduct the research. Foremost among these limitations is the small number and self-selected nature of the respondents. The responses of the 48 individuals who chose to complete the survey are unlikely to fully reflect the views and practices of all academic research libraries in ARL, ASERL, and GWLA. As Baker and Dube note in their error analysis of research conducted using a similar method, possible shortcomings of online surveys of library personnel with designated work responsibilities include uncertainties about whether all appropriate individuals in the surveyed population received an invitation and about why some individuals that did receive the invitation opted not to respond. ${ }^{28}$ Among the potential reasons for nonresponses are a lack of time or interest and a perception of being unqualified to provide the information the survey requested.

Beyond nonresponses, further factors may have limited the accuracy of the survey's results. Because the survey was anonymous, the researcher has no way to verify the information that the respondents reported regarding their libraries' consortia memberships, FTE, and budgets. Likewise, the information that the respondents provided about their libraries commitments to perpetual journal access are subjective perceptions and may not fully represent actual views and practices within their libraries. Finally, although the researcher took efforts to prevent the receipt of multiple responses from a single library, this may have occurred. If multiple responses were submitted by one or more libraries, these libraries' views and practices will have been overrepresented within the survey's results.

Another potential problem is apparent within the options provided in response to question 2, which asked for the FTE of the respondents' libraries. More than half of the respondents replied to this question by selecting the maximum response option listed: "greater than 25,000." This stratification implies that the survey would have offered more nuanced insights into the relationship between FTE and perpetual access views and practices had the response options for question 2 included more varied FTE ranges.

\section{Discussion}

Despite the survey's limitations, its results contain valuable insights regarding academic research libraries' views and practices concerning perpetual journal access. Foremost among these insights is that most libraries appear to espouse a commitment to securing perpetual access provisions regardless of whether their budgets are increasing or decreasing, though some minor variances by size are evident. Moreover, the results suggest that, among almost all libraries, these espoused commitments are either holding steady or increasing. Although the emerging age of information technology may raise questions about the return on investment of perpetual access commitments, the survey results suggest that libraries regard these commitments as being of core importance. The high value ascribed to perpetual access is reflected in several replies submitted to the survey's last question, which was an open-ended query inviting the respondents to share additional input about the survey's topic (see appendix B for a full listing of responses). One respondent stated,

Securing perpetual access is essential for meeting a core value of academic librarianship, that being to preserve scholarly communications. Supporting LOCKSS and Portico is one small way to ensure permanent access, but these services are not enough. Libraries must continue to make good decisions about the long-term access to information. 
Likewise, the comments of another respondent indicate that the increasing commitment to perpetual access within the respondent's library is leading the library to renegotiate many of its license agreements to secure stronger perpetual access provisions.

The strength of the respondent libraries' claimed commitments to perpetual access are notable in their contrast to the findings reported in 2006 by Stemper and Barribeau. ${ }^{29}$ Whereas these authors found that more than 80 percent of research libraries in North America will acquire an e-resource even if the acquisition lacks perpetual access provisions, responses to the present survey indicate that almost two-thirds of the respondents' libraries always or usually consider the lack of perpetual access provisions to be a deal-breaker. One factor that may account for this difference in findings is the resources being considered. This paper's survey instructed respondents to exclude from their considerations full-text aggregator subscriptions, nonsubscribed titles that become available through publisher packages, and pay-per-view transactions. In contrast, Stemper and Barribeau's findings, which they culled from several different sources, did not make these exclusions. Beyond these methodological differences, other factors may be behind the increased commitment to perpetual access. One such possibility is that libraries have followed the recommendations of the chorus of voices in the professional literature advocating for more stringent commitments to perpetual access. The downturn in the economy and its negative impact on material budgets may be another factor behind the increased commitment to perpetual access. The likelihood of cancellations may be bringing to light the importance of provisions ensuring that access to subscribed content is retained if subscriptions are discontinued.

While the survey's results indicate strong commitments to perpetual access, the findings have another side. Indeed, aspects of the results suggest that the necessity of achieving perpetual access is being affirmed, but these commitments also are being questioned in light of the competing priority of meeting patrons' immediate needs and the fact-evidenced in responses to question 10 - that the lack of perpetual access provisions has so far only resulted in minor losses in access. This sentiment is reflected in the following comment:

In most cases the immediate need for the content is more important than provisions for perpetual access. While faculty are very vocal in expressing their need for online and remote access, few faculty voice any concern for perpetual access issues and none talk of the increased cost involved to secure perpetual access. While we have lost access to content as subscriptions were canceled, in the overall picture, this has been a minor inconvenience.
Another comment shows a similar awareness of the opportunity cost of pursuing perpetual access:

Philosophically, it is great to have perpetual access. But in practical terms, vendors tend to charge more for that, which means you have less money to spend on other journals. So, perpetual access to your collection typically means that you have a smaller collection. Sometimes the trade-off is worth it and sometimes it isn't.

In addition to these comments, willingness to compromise on perpetual access commitments is indicated in responses to questions 8 and 9 , which asked about current and anticipated impacts of budget cuts. These responses show that, despite espoused commitments to perpetual access, most of the respondents' libraries have or are planning to address budget cuts by taking actions that compromise perpetual access. Most frequently, this compromise takes the form of cancelling subscribed access to journals in favor of access through full-text aggregators, which usually lack perpetual access provisions. The likely rationale for such decisions is that broader access with compromised perpetual access provisions is preferable to less access with uncompromised perpetual access provisions. Regarding the actions that the respondents anticipate their libraries will take because of budget cuts, the strong interest in uptake of pay-per-view is of particular significance. This appears to indicate a growing interest in patron-driven acquisition models that address the immediate needs of individual patrons as those needs arise rather than the development of collections that have been carefully calibrated to anticipate patron needs before they arise. Moreover, given that the model is oftentimes implemented in place of a subscription in cases where a resource is only used occasionally, the interest in pay-per-view suggests a particular willingness to compromise on perpetual access for materials that currently receive low use.

\section{Conclusion}

This paper sought to examine the commitments of academic research libraries to securing provisions for perpetual journal access. By first considering this topic within the contexts of the past, present, and future, the paper outlined reasons why libraries have sought perpetual access provisions and suggested how opportunity costs and emerging developments in the information marketplace may be affecting these commitments. Ostensibly, the survey's results indicate strong perpetual access commitments, but this finding is undermined by libraries' actions. Indeed, the results bring to light a fundamental disconnect: while libraries broadly 
affirm the need for securing perpetual journal access provisions, many are compromising these provisions and expect to continue doing so in the future.

As was noted earlier in the paper, this contrast between actions and ideals was previously highlighted in research by Rogers and Stemper and Barribeau. ${ }^{30}$ The conclusion of these authors, and of most others that address the topic of perpetual journal access, is that libraries need to more stringently pursue perpetual access provisions to reconcile their actions and ideals. It is largely on this basis, for example, that a 2006 CLIR report on journal archiving makes as its first recommendation to libraries that they not renew subscriptions to any journals published by organizations that fail to provide libraries with full perpetual access provisions. ${ }^{31}$

Given this precedent established in earlier studies, the conclusion that most readily suggests itself is to echo previous researchers' recommendations by reiterating with heightened stringency the need for libraries to finally stop compromising perpetual access rights and thereby align practices with ideals. Although this recommendation is valuable for the clear path it charts, the fact that libraries remain willing to sacrifice perpetual access, when pressed, to meet other priorities suggests that what may be of most value is introspection. Through a process of self-analysis and critical thinking, the profession needs to understand and articulate the implicit factors that lead libraries to decide that perpetual access is less important than other priorities. For example, what predictions are libraries making about the future of the information marketplace and the roles of libraries in this environment? What value judgments are at work when weighing the immediate needs of current patrons against anticipated needs of future patrons? What effect is the growing role of consortia and collective archiving of library collections having on perpetual access commitments?

Addressing these questions will undoubtedly be challenging. However, as the transition from print to electronic formats broadens to include more books, media, and other portions of collections, it is of increasing importance that academic research libraries embrace this challenge. By doing so, they will develop a stronger theoretical basis for making decisions about the extent to which perpetual access commitments truly are essential.

\section{References}

1. Angela Riggio et al., Report of the Digital Library Federation Electronic Resource Management Initiative, Appendix D: Data Element Dictionary (Washington, D.C.: Digital Library Federation, 2004): 26, www.diglib.org/pubs/dlf102/dlfermi0408appd.pdf (accessed Apr. 25, 2010).

2. James Raven, ed., Lost Libraries: The Destruction of Great Book Collections Since Antiquity (Houndmills, Basingstoke, Hamsphire, UK: Palgrave Macmillan, 2004).

3. Barbra Buckner Higginbotham, Our Past Preserved: A History of American Library Preservation, 1876-1910 (Boston: G. K. Hall, 1990); Larry McDonald, "Forgotten Forebears: Concerns with Preservation, 1876 to World War I," Libraries of Culture 25, no. 4 (1990): 483-95.

4. Higginbotham, Our Past Preserved, 1, 188-89; Deanna Marcum and Amy Friedlander, "Keepers of the Crumbling Culture: What Digital Preservation Can Learn from Library History," D-Lib Magazine 9, no. 5 (2003), www.dlib.org/ dlib/may03/friedlander/05friedlander.html (accessed Apr. 25, 2010).

5. Nancy Kalikow Maxwell, Sacred Stacks: The Higher Purpose of Libraries and Librarianship (Chicago: ALA, 2006): 52, 59.

6. Karla Hahn and Julia Blixrud, "Preface," in Lars Meyer, Safeguarding Collections at the Dawn of the 21st Century: Describing Roles of Measuring Contemporary Preservation Activities in ARL Libraries (Washington, D.C.: ARL, 2009): 5, www.arl.org/bm doc/safeguarding-collections.pdf (accessed Apr. 25, 2010).

7. Donald J. Waters, ed., "Urgent Action Needed to Preserve Scholarly Electronic Journals," statement, Andrew W. Mellon Foundation, Oct. 15, 2005, www.diglib.org/pubs/ waters051015.pdf (accessed Apr. 25, 2010).

8. Ibid.

9. Anne R. Kenney et al., E-Journal Archiving Metes and Bounds: A Survey of the Landscape (Washington, D.C.: Council on Library \& Information Resources, 2006), www. clir.org/pubs/reports/pub138/pub138.pdf (accessed Apr. 25, 2010).

10. Ross Atkinson, "Six Key Challenges for the Future of Collection Development: Introduction for the Janus Breakout Sessions," Library Resources \& Technical Services 50, no. 4 (2006): 245.

11. Robert Darnton, The Case for Books: Past, Present, and Future (New York: Public Affairs, 2009): 21-23.

12. Ibid., 23.

13. Peter Morville, Ambient Findability (Sebastopol, Calif.: O’Reilly, 2005): 6.

14. Chris Anderson, The Long Tail: Why the Future of Business Is Selling Less of More (New York: Hyperion, 2006).

15. Dan Hazen, "Rethinking Research Library Collections: A Policy Framework for Straitened Times, and Beyond," Library Resources \& Technical Services 54, no. 2 (2010): 120.

16. T. Scott Plutchak, "What's a Serial When You're Running on Internet Time?" The Serials Librarian 52, no. 1/2 (2007): 89.

17. John M. Budd, The Changing Academic Library: Operations, Culture, Environments (Chicago: ALA, 2005): 218-19; Walt Crawford and Michael Gorman, Future Libraries: Dreams, Madness, \& Reality (Chicago: ALA, 1995): 133.

18. George Stachokas, "Electronic Resources and Mission Creep: Reorganizing the Library for the Twenty-First Century," Journal of Electronic Resources Librarianship 21, no. 3 (2009): 206-12.

19. Matt Barnes, "The Invisible Mainstream: E-Resources in Workflows and Organizations" (presentation, Electronic Resources \& Libraries, Los Angeles, Febr. 11, 2009).

20. Jim Stemper and Susan Barribeau, "Perpetual Access to Electronic Journals: A Survey of One Academic Research Library's Licenses," Library Resources \& Technical Services 
50, no. 2 (2006): 91-109.

21. Sam Rogers, "Survey and Analysis of Electronic Journal Licenses for Long-Term Access Provisions in Tertiary New Zealand Academic Libraries," Serials Review 35, no. 1 (2009): 3-15.

22. Stemper and Barribeau, "Perpetual Access to Electronic Journals."

23. Hazen, "Rethinking Research Library Collections," 120.

24. Thomas H. Teper, "Current and Emerging Challenges for the Future of Library and Archival Preservation," Library Resources \& Technical Services 49, no. 1 (2005): 32-39.

25. Ibid., 38 .

26. Martha Kyrillidou and Les Bland, eds., ARL Statistics 20072008 (Washington, D.C.: Association of Research Libraries, 2009): 67, www.arl.org/bm doc/arlstat08.pdf (access Apr. 26, 2010); Association of Southeastern Research Libraries,
ASERL-2008-stats, 39. Full-time students, undergraduate and graduate, www.aserl.org/stat/2008/ASERL-2008-stats.xls (accessed Apr. 26, 2010).

27. Kyrillidou and Bland, ARL Statistics 2007-2008, 46; Association of Southeastern Research Libraries, ASERL2008-stats, 15.b. Expenditures for current serials, including periodicals.

28. Whitney Baker and Liz Dube, "Identifying Standard Practices in Research Library Book Conservation," Library Resources \& Technical Services 54, no. 1 (2010): 29.

29. Stemper and Barribeau, "Perpetual Access to Electronic Journals."

30. Ibid.; Rogers, "Survey and Analysis of Electronic Journal Licenses for Long-term Access Provisions in Tertiary New Zealand Academic Libraries."

31. Kenney et al., E-Journal Archiving Metes and Bounds.

\section{Appendix A. Survey Instrument}

1. My library is a member of the:

Association of Research Libraries

Association of Southeastern Research Libraries

Greater Western Library Alliance

2. The full-time enrollment of my library's parent institution is:

Less than 10,000

Between 10,000-15,000

Between 15,001-20,000

Between 20,001-25,000

Greater than 25,000

Not sure

3. To the best of my knowledge, in the current fiscal year, my library's budget for the acquisition of journal content (including individual subscriptions in all formats, publisher packages, full-text aggregators, and pay-per-view transactions; but excluding one-time backfile purchases and associated access fees) is:

Less than $\$ 1,000,000$

Between $\$ 1,000,000-\$ 2,000,000$

Between $\$ 2,000,000-\$ 3,000,000$

Between \$3,000,000-\$4,000,000

Between $\$ 4,000,000-\$ 5,000,000$

Between $\$ 5,000,000-\$ 6,000,000$

Between $\$ 6,000,000-\$ 7,000,000$

Between $\$ 7,000,000-\$ 8,000,000$

Greater than $\$ 8,000,000$

Not sure

4. In comparison to the previous fiscal year, my library's budget for the acquisition of journal content has:

Decreased by more than 20 percent

Decreased by 10-20 percent

Decreased by 1-9 percent

Remained flat

Increased by 1-9 percent

Increased by $10-20$ percent

Increased by more than 20 percent 
5. Excluding full-text aggregator subscriptions, non-subscribed titles that become available through publisher packages, and pay-per-view transactions, how important does your library consider securing perpetual access provisions to the journal content it acquires?

Essential (lack of these provisions is almost always a deal-breaker)

- Very important (lack of these provisions is generally a deal-breaker)

- Somewhat important (lack of these provisions is sometimes a deal-breaker)

_ Not very important (lack of these provisions is generally not a deal-breaker)

Unimportant (lack of these provisions is almost never a deal-breaker)

_ Not sure

6. Securing perpetual access provisions for journals is:

Becoming more of a priority to my library

Becoming less of a priority to my library

Remaining at the same level of priority at my library

_ Not sure

7. Which provisions does your library generally consider to be satisfactory for ensuring perpetual access?

Participation in an e-journal archiving initiative such as LOCKSS or Portico

License agreement provisions stating that ongoing access will be provided via a web platform free of charge

_ License agreement provisions stating that ongoing access will be provided via a web platform subject to a reasonable annual access fee

License agreement provisions stating that ongoing access will be provided through the transmission of files that must be locally hosted by the library

Ownership of the content in print or microform

Perpetual access is not a concern at my library; therefore, any provisions (or lack thereof) are satisfactory

Not sure

8. Budgetary factors have forced my library to:

Discontinue participation in one or more journal archiving initiative (e.g., LOCKSS Alliance and Portico)

Cancel subscribed journal access due to aggregator access of the cancelled content

_ Convert subscribed journal access to access through pay-per-view transactions

_ Convert print subscriptions to online only subscriptions that do not include perpetual access provisions

_ Downgrade subscribed journal access to subscription levels with decreased perpetual access provisions

_ None of the above

9. I think that in the next few years, budgetary factors are likely to force my library to:

Discontinue participation in one or more journal archiving initiative (e.g., LOCKSS Alliance and Portico)

Cancel subscribed journal access due to aggregator access of the cancelled content

Convert subscribed journal access to access through pay-per-view transactions

- Convert print subscriptions to online only subscriptions that do not include perpetual access provisions

— Downgrade subscribed journal access to subscription levels with decreased perpetual access provisions

- None of the above

10. To present, the loss of access to journal content due to the lack of perpetual access provisions has resulted in:

_ Major losses in access that have had a significant impact on my library's ability to support the research, teaching, and learning of its user community

_ Minor losses in access that have had a small impact on my library's ability to support the research, teaching, and learning of its user community

No losses in access

— Not sure

11. Use this space if you would like to share any additional information or views about the commitment of research libraries to securing perpetual access provisions for journal acquisitions. 


\section{Appendix B. Responses to Question 11, an Open-Ended Question Asking Respondents to Share Additional Information or Views about the Commitment to Perpetual Access*}

- Despite our ostensibly being a research institution, comprehensive collection building (including perpetual access issues) has not been a focus.

- In most cases the immediate need for the content is more important than provisions for perpetual access. While faculty are very vocal in expressing their need for online and remote access, few faculty voice any concern for perpetual access issues and none talk of the increased cost involved to secure perpetual access. While we have lost access to content as subscriptions were canceled, in the overall picture, this has been a minor inconvenience.

- LOCKSS and Protico are an expensive waste of time and money. If content has value, it will survive. Let the market work it out.

- My latest area of concern is when publishers sell journals to new publishers. Sometimes the new publisher has no perpetual access provisions and the old publisher did not commit themselves to ensuring that the customers who paid for access under the understanding that they would retain access to paid content.

- Philosophically, it is great to have perpetual access. But in practical terms, vendors tend to charge more for that, which means you have less money to spend on other journals. So, perpetual access to your collection typically means that you have a smaller collection. Sometimes the trade-off is worth it and sometimes it isn't.

- Securing perpetual access is essential for meeting a core value of academic librarianship, that being to preserve scholarly communications. Supporting LOCKSS and Portico is one small way to ensure permanent access, but these services are not enough. Libraries must continue to make good decisions about the long-term access to information.

- Securing perpetual access is the first step. Managing perpetual access rights after a journal is canceled is a workflow issue/challenge (archival access verification).

- Some of the major challenges in perpetual access provisions are: journal transfers, publisher mergers (Wiley Blackwell being the biggest one where it will probably take some time to still figure out how our former big deals and their perpetual access provisions will be honored); and small publishers that don't have appropriate systems for keeping track of the online subscriptions.

- There are some journals that still have rolling-year access for the online (with no perpetual access for the oldest year as it drops off); we have had to stick with print + electronic or even return to print in such cases. We do have content from cancelled titles on DVD or flashdrives but have no place to provide access to the content and these have not been processed (no catalog entries, for example). Most of the perpetual access clauses I add to licenses are in the "will supply content in the appropriate format at the time" format, as there are still so many publishers who are not working with LOCKSS, CLOCKSS, or Portico.

- We also use direct e-mail to publishers to verify their position on provision of perpetual access. Most licenses still do not speak to this issue.

- We are re-negotiating many journal subscription licenses now and working to secure better post-canellation access rights to the years subscribed than we may have had in the past. (Securing post-cancellation rights has always been important.) In addition, we are also looking to experiment with pay-per-view models for journal articles and books-ondemand to increase patrons' access to materials we may not be able to purchase.

- We cancelled $\$ 1.5$ million worth of journals and databases for 2010. There have been some unexpected losses where we thought we had perpetual access. We also lost access to many unsubscribed titles due to a consortium cancellation of a "big deal" package. The members are still sorting out which titles should have perpetual access for the members. A very big and complex workload.

- We try to ensure perpetual access, but individual selectors will sometimes be willing to go with an electronic-only subscription without such protection in order to fulfill user expectations and stay within budget. It's hard to say how this will impact our collection in the future. We really hope that LOCKSS and Portico will be viable long term solutions to ensuring perpetual access. Even if you have a signed license and then the title transfers to another publisher, perpetual access may not be honored by the new publishers.

${ }^{*}$ The researcher made minor edits to responses to correct misspellings and grammatical errors. 